\title{
BARONG LANDONG: FUNGSI DAN PELESTARIANNYA SEBAGAI IDENTITAS BUDAYA ORANG LEMBAK DI KOTA BENGKULU
}

\section{BARONG LANDONG: FUNCTION AND CONSTRUCTION AS A CULTURAL LOCAL IDENTITY IN BENGKULU CITY}

\author{
Rois Leonard Arios \\ Balai Pelestarian Nilai Budaya Sumatera Barat \\ Jl. Raya Belimbing No. 16A Kuranji Padang \\ Surel:rolear72@yahoo.co.id
}

\begin{abstract}
Abstrak
Kesenian rakyat yang lahir dari masyarakat dapat menjadi identitas bagi masyarakat atau sebuah suku bangsa jika kesenian tersebut masih dimanfaatkan oleh masyarakatnya. Penelitian ini menganalisis dan mendeskripsikan barong landong sebagai sebuah kesenian suku bangsa Lembak di Kota Bengkulu. Penelitian dilakukan dengan pendekatan kualitatif dengan mewancarai aktor-aktor yang terlibat dalam pembuatan, pertunjukan, dan upaya pelestarian. Hasil penelitian menunjukkan adanya perubahan fungsi kesenian barong landong. Secara fungsional barong landong masih tetap eksis tetapi tidak lagi menjadi identitas budaya orang Lembak tetapi sudah menjadi milik komunal masyarakat Bengkulu.
\end{abstract}

Kata kunci: barong landong, fungsi dan struktur, identitas, pelestarian

\begin{abstract}
Art of the people born from the community can be an identity for the community or a tribe if the art is still used by the community. This research analyzes and describes barong landong as an art of Lembak tribe in Bengkulu City. The research is conducted by qualitative approach by interviewing the actors involved in making, performing, and preservation efforts. The result of the research shows the change of function of barong landong art. Functionally barong landong still exist but no longer become the cultural identity of the people of Lembak but already belongs to communal society Bengkulu.
\end{abstract}

Keywords: barong landong, function and structure, identity, preservation

\section{PENDAHULUAN}

Kesenian merupakan salah satu unsur budaya yang paling menonjol, dan kesenian itu sendiri terdiri dari banyak cabang serta macam. Diantaranya adalah musik, tari dan sastra yang merupakan hasil seni budaya suatu daerah yang sangat erat hubungannya dengan lingkungan masyarakat pendukungnya. Hal ini menunjukkan bahwa seni tradisonal tidak berdiri sendiri dan tidak dapat terlepas dari masyarakat pendukungnya apabila keberadaannya masih difungsikan 
sebagai salah satu bagian kehidupan. Kesenian merupakan pengungkapan kreatifitas manusia dengan masyarakat sebagai penyanggahnya. Keberadaannya tidak mandiri tetapi luluh lekat dengan adat, pandangan hidup, tata masyarakat, kepercayaan yang secara turun temurun telah diakui keberadaannya oleh masyarakat di lingkungan kebudayaan itu lahir.

Usaha untuk melestarikan serta mengembangkan kesenian masih mengalami kemunduran yang diakibatkan generasi muda yang cendrung lebih menyenangi musik-musik yang berbau modern, sehingga keberadaan seni yang ada di daerah setempat seperti seni tradisi yang terdapat di wilayah Kota Bengkulu mengalami kemundura. Contohnya, para mudamudi lebih senang bermain gitar, drum, atau orgen daripada bermain alat-alat musik tradisi seperti Redap, Serunai, dan sejenis alat musik etnis lainnya.

Budaya Bengkulu terbentuk dari pertemuan berbagai etnis yang bermigrasi ke Kota Bengkulu. Etnis-etnis tersebut mendapat pengaruh dari budaya yang dibawa oleh kolonial sehingga memunculkan budaya baru. Menurut beberapa catatan, masyarakat Melayu Bengkulu sendiri merupakan perpaduan (asimilasi) budaya rejang dan minangkabau dan mendapat pengaruh dari berbagai etnis yang datang ke Bengkulu seperti Bugis, Cina, Arab, Jawa, Aceh, Palembang, dan India (Anwar, 2004:73).

Perpaduan berbagai budaya ini membawa pengaruh dalam bidang kesenian. Hal ini bisa dilihat pada suku bangsa Melayu Bengkulu dan suku bangsa Lembak Delapan yang merupakan suku bangsa asli Kota Bengkulu. Kesenian ini selalu ditampilkan pada acara-acara adat maupun perayaan-perayaan tertentu. Perkembangan selanjutnya semakin banyak jenis kesenian yang menjadi khas Melayu Bengkulu seperti gamat, talibun, tari selendang, tari sapu tangan, pencak silat, tari mabuk, tari piring, dan lain-lain. Disamping itu terkait dengan agama Islam terdapat juga kesenian hadra, syarafal anam, dan qasyidah (Hamidy, 1991/1992: 53; Iriani, dkk. 2008. 97-106). Sedangkan Suku bangsa Lembak Delapan menyebar hingga ke wilayah Kabupaten Bengkulu Tengah, Kabupaten Bengkulu Utara, Kabupaten Rejang Lebong, hingga ke wilayah Propinsi Sumatera Selatan. Suku bangsa Lembak ini memiliki varian masingmasing tergantung wilayahnya. Salah satu kesenian yang khas yaitu Barong Landong.

Barong Landong merupakan boneka raksasa yang menyerupai manusia berukuran tinggi $250 \mathrm{~cm}$ lebar $100 \mathrm{~cm}$ dengan rangka terbuat dari rotan, bambu, dan kayu. Rangka tersebut dibungkus dengan kain khas pengantin Lembak. Sedangkan bagian kepala dibuat dari kayu yang diukir menyerupai wajah manusia. Kesenian ini diyakini oleh masyarakat Lembak berasal dari KelurahanTanjung Agung Kecamatan Sungai Serut Kota Bengkulu. 
Barong Landong dapat diklasifikasikan sejenis antara lain dengan Reog Ponorogo, Barongsai, Ondel-Ondel Betawi, dan Barong Landung Bali. Terkait Barong Landong pada suku bangsa lembak memiliki kesemaan bentuk dengan Ondel-Ondel Betawi, memiliki kesamaan nama dengan Barong Landung di Bali namun belum diperoleh kesepahaman diantara para pelaku seni Barong Landong Lembak terkait hubungan di antara kesenian lainnya tersebut. Barong Landong hampir serupa dengan kesenian ondel - ondel dari daerah Betawi,hanya saja kalau di perhatikan secara seksama bagian kepala barong landong memiliki ukuran yang lebih kecil dan terbuat dari bahan kayu, sedangkan ondel -ondel bagian kepalanya terbuat dari bahan kertas atau plastik dan memiliki ukuran yang jauh lebih besar.Musik yang mengiringi Ondel ondel di Betawi adalah Tanjidor sedangkan pada Barong Landong diiringi oleh Rebana/gendang panjang, kulintang serta serunai (Wawancara dengan Bapak Tajuddin, 4 Maret 2017),

Hidayanto (2012: 137) misalnya menjelaskan kesenian Reog Ponorogo ditampilkan sengan tujuan sebagai hiburan dan bagian dari upacara (komunal, individual atau keluarga). Konteks reog menyangkut tiga permasalahan dasar:

1. Fungsi, yaitu mengenai kegunaan atau peranan seni reog Ponorogo dalam masyarakat.

2. Praktik, termasuk teknik pengaturan waktu dan tempat; yaitu bagaimana pertunjukkan reog diadakan atau bagaimana reog dibuat dan dijual.

3. Hubungan atau peranan antara kesenian, seniman, penyelenggara dan penontonnya. Misalnya apakah reog tersebut buatan sendiri, warisan leluhur, diberi atau dibeli dari orang lain. Demikian pula antara penanggap (yang mengundang) dengan pemain, penonton undangan, penonton tidak diundang, dan sebagainya,

Jenis kesenian lainnya seperti Baleganjur pada masyarakat Kabupaten Karanganyar Jawa Tengah memiliki fungsi utama sebagai sarana keagamaan (pemujaan) sedangkan pada perkembangan selanjutnya sudah berfungsi menjadi sarana hiburan pada kegiatan keramaian seperti penyambutan tamu (Triadi, dkk. 2016).

Barong Landong diyakini sudah ada sejak tahun 1800-an atau akhir abad ke-19 namun sempat menghilang sekitar 50 tahun. Baru pada tahun 1990 mulai diangkat kembali walau hanya dalam bentuk tulisan dan belum dalam pertunjukan. Tahun 2012 mulai dibuat kembali dan ditampilkan pada aktivitas perayaan seperti festival tabut dan prosesi menyambut tamu negara. Dengan demikian sudah berbeda dengan fungsi awalnya sebagai perayaan pesta panen sudah tidak pernah lagi ditampilkan. Pada proses memunculkan kembali barong landong oleh para seniman dan tokoh adat Lembak, merasa kesulitan karena tokoh yang benar-benar 
memahami kesenian ini sudah banyak yang meninggal. Dengan demikian mereka mencoba mengkonsepsikan barong landong dengan konsep seperti saat ini. Dari uraian tersebut dapat dirumuskan pertanyaan penelitian yaitu bagaimana fungsi dan pewarisan barong landong pada suku bangsa Lembak saat ini.

Tujuan penelitian adalah mendeskripsikan barong landong sebagai identitas budaya suku bangsa lembak di Kota Bengkulu terkait struktur barong landong, fungsi bagi masyarakat Lembak dan atau pemerintah, dan pelestarian yang dilakukan.

Kebudayaan ditinjau dari wujudnya paling sedikit mempunyai tiga wujud, yaitu wujud sebagai suatu komplek gagasan, konsep, dan pikiran manusia, wujud sebagai komplek aktivitas, wujud sebagai benda. Dari tiga wujud tersebut secara universal kebudayaan terdiri dari 7 unsur yaitu: (1) bahasa, (2) sistem teknologi, (3) sistem mata pencarian hidup atau ekonomi, (4) organisasi sosial, (5) sistem pengetahuan, (6) religi, dan (7) kesenian (Koentjaraningrat, 1986: 186-188).

Sifat universal tersebut berarti setiap suku bangsa memiliki ketujuh unsur tersebut dengan bentuk dan pemaknaan yang berbeda-beda. Demikian pula halnya pada unsur kesenian, dengan bentuk dan pemanknaan masing-masing, kesenian diciptakan oleh manusia untuk mendapatkan rasa keindahan. Kesenian merupakan unsur kebudayaan yang bersumber pada rasa, terutama rasa keindahan yang ada pada manusia. Rasa keindahan itu dapat disentuh lewat panca indra, yaitu lewat penglihatan mata, pendengaran telinga, penciuman hidung, perasaan lidah, dan perasaan pucuk jari-jari yang sudah sejak lama tumbuh dan berkembang dalam suatu kehidupan masyarakat (Soemardjan, 1980/1981: 19).

Eksistensi kesenian dalam masyarakat terkait dengan fungsi dan makna kesenian bagi masyarakat.. Secara konseptual, fungsi berarti hubungan fungsi tersebut dengan organisme sosial (Soemardjan, 1980/1981: 19). Budhisantoso (1991) mengatakan terdapat delapan macam fungsi sosial yaitu sebagai: (1) sarana kesenangan; (2) bersantai atau hiburan; ungkapan jati diri; (3) sarana jati diri; (4) sarana integratif; (5) sarana penyembuhan (therapeutic significance); (6) sarana pendidikan; (7) sarana integrasi dalam masa kacau; (8) lambang yang penuh makna dan mengandung kekuatan. Sedangkan Soedarsono (1995) melihat fungsi seni, terutama dari hubungan praktis dan intergritasnya yang direduksi menjadi tiga fungsi utama, yaitu: (1) untuk kepentingan sosial atau sarana upacara; (2) sebagai ungkapan perasaan pribadi yang dapat menghibur diri; dan (3) sebagai penyajian estetik. 
Merriam (1964: 219 - 226) menjelaskan fungsi dan kegunaan musik dalam kesenian yang dalam penelitian ini dapat dipakai sebagai kerangka pemikiran dalam melihat fungsi kesenian barong landong. Merriam mengatakan terdapat 10 fungsi musik pada masyarakat yaitu:

1. Fungsi musik sebagai pengungkapan emosional, disini musik berfungsi sebagai suatu media bagi seseorang untuk mengungkapkan perasaan atau emosinya. Dengan kata lain si pemain dapat mengungkapkan perasaan atau emosinya nelalui musik.

2. Fungsi musik sebagai penghayatan estetis, musik merupakan suatu karya seni. Suatu karya dapat dikatakan karya seni apabila dia memiliki unsur keindahan atau estetika di dalamnya. Melalui musik kita dapat merasakan nilai-nilai keindahan baik melalui melodi atupun dinamikanya.

3. Fungsi musik sebagai hiburan, musik memiliki fungsi hiburan mengacu kepada pengertian bahwa sebuah musik pasti mengandung unsur-unsur yang bersifat menghibur. Hal ini dapat dinilai dari melodi ataupun liriknya.

4. Fungsi musik sebagai komunikasi, musik memiliki fungsi komunikasi berarti bahwa sebuah musik yang berlaku di suatu daerah kebudayaan mengandung isyarat-isyarat tersendiri yang hanya diketahui oleh masyarakat pendukung kebudayaan tersebut. Hal ini dapat dilihat dari teks atau pun melodi musik tersebut.

5. Fungsi musik sebagai perlambangan, musik memiliki fungsi dalam melambangkan suatu hal. Hal ini dapat dilihat dari aspek-aspek musik tersebut, misalmya tempo sebuah musik. Jika tempo sebuah musik lambat, maka kebanyakan teksnya menceritakan hal-hal yang menyedihkan. Sehingga musik itu melambangkan akan kesedihan.

6. Fungsi musik sebagai reaksi jasmani, jika sebuah musik dimainkan, musik itu dapat merangsang sel-sel saraf manusia sehingga menyebabkan tubuh kita bergerak mengikuti irama musik tersebut. Jika musiknya cepat maka gerakan kita cepat, demikian juga sebaliknya.

7. Fungsi musik sebagai yang berkaitan dengan norma sosial, musik berfungsi sebagai media pengajaran akan norma-norma atau peraturan-peraturan. Penyampaian kebanyakan melalui teks-teks nyanyian yang berisi aturan-aturan.

8. Fungsi musik sebagai pengesahan lembaga social, fungsi musik disini berarti bahwa sebuah musik memiliki peranan yang sangat penting dalam suatu upacara. Musik 
merupakan salah satu unsur yang penting dan menjadi bagian dalam upacara, bukan hanya sebagai pengiring.

9. Fungsi musik sebagai kesinambungan budaya, fungsi ini hampir sama dengan fungsi yang berkaitan dengan norma sosial. Dalam hal ini musik berisi tentang ajaran-ajaran untuk meneruskan sebuah sistem dalam kebudayaan terhadap generasi selanjutnya.

10. Fungsi musik sebagai pengintegrasian masyarakat, musik memiliki fungsi dalam pengintegrasian masyarakat. Suatu musik jika dimainkan secara bersama-sama maka tanpa disadari musik tersebut menimbulkan rasa kebersamaan diantara pemain atau penikmat musik itu.

Untuk memahami fungsi kesenian barong landong pada suku bangsa Lembak dilakukan dengan pendekatan struktural fungsional. Menurut Damsar (2015:169-174) secara umum pemikiran struktural fungsional mengasumsikan masyarakat sebagai berikut:

1. Masyarakat terdiri dari berbagai elemen yang terstruktur secara relatif mantap dan stabil;

2. Elemen-elemen terstruktur tersebut terintegrasi dengan baik;

3. Setiap elemen memiliki fungsi agar struktur tersebut bertahan dalam sistem

4. Struktur yang fungsional dilandasi oleh konsensus nilai diantara para anggotanya

Dengan asumsi struktural fungsional tergambar bahwa kesenian barong landong memiliki elemen-elemen pendukung yang terstruktur secara mantap seperti pembuat barong landong, pemimpin upacara, pemain musik, penonton, dan lain-lain. Elemen-elemen tersebut akan bekerja sesuai fungsinya sehingga mewujudkan kesenian barong landong yang dipahami bersama. Segala tindakan orang-orang yang terlibat dalam kesenian barong landong didasarkan pada pemahaman nilai-nilai yang berlaku termasuk segala hal-hal boleh dan tidak boleh dilakukan dalam pertunjukan barong landong. Jika seluruh elemen dalam kesenian barong landong bekerja dengan baik sesuai dengan fungsinya, maka kesenian tersebut akan selalu eksis. Sehingga dengan demikian kesenian barong landong sebagai sistem kesenian tradisi suku bangsa Lembak terbatas sebagai kesenian suku bangsa Lembak. Kehidupannya diatur oleh fungsinya sebagai kesenian ritual dan sekuler serta dipengaruhi maknanya oleh struktur sosial.

\section{METODE PENELITIAN}

Penelitian ini menggunakan metode penelitian kualitatif deskriptif yang bersifat holistikintegratif, thick description, dengan analisa deskriptif kualitatif. Pendekatan kualitatif dipilih 
karena mampu menganalisis proses-proses sosial dan makna yang terdapat pada fenomena yang tampak di permukaan. Dengan demikian dengan pendekatan ini, penelitian ini bukan hanya sekedar menjelaskan fakta tetapi juga proses dan makna dibalik fakta tersebut (Bungin. 2007:144). Mengutip tulisan Strauss dan Corbin bahwa metode penelitian kualitatif dipilih karena sifat dan masalah penelitian yang diteliti yaitu memberi rincian yang kompleks tentang fenomena yang sulit ditangkap oleh penelitian kuantitatif. Metode ini juga dapat dipakai untuk memahami makna dibalik fenomena yang belum diketahui dan memantapkan wawasan terhadap sesuatu yang baru atau yang masih sedikit diketahui (Strauss dan Corbin. 2003).

Data primer penelitian diperoleh dari hasil wawancara dengan informan yang memahami dan yang terlibat dengan kesenian Barong Landong yang diperoleh melalui sistem snowball yang jumlahnya tergantung pada kecukupan data (purpossive sampling). Data awal diperoleh dari kepala Taman Budaya Bengkulu yaitu Bapak Buyung Asril. Beliau menjelaskan peranan taman budaya dalam pengelolaan kesenian di Propinsi Bengkulu, selanjutnya melalui staf beliau bernama Gopal menjelaskan kesenian Barong Landong dan seniman-seniman yang terlibat di dalamnya. Melalui Bapak Gopal tersebut maka didapat beberapa nama yaitu Bapak Tajuddin, lalu melalui Bapak Tajuddin didapat nama Bapak Bestari Marzuki dan nama Bapak S. Effendi (ketua BMA Kota Bengkulu. Data juga diperoleh dari Museum Negeri Propinsi Bengkulu berupa pengamatan terhadap barong landong koleksi museum dan wawancara dengan Bapak Muhardi dan Bapak Devi sebagai pegawai museum sekaligus pembuat barong landong.

\section{PEMBAHASAN}

\section{Sekilas Gambaran Kota Bengkulu}

Kota Bengkulu merupakan ibukota Provinsi Bengkulu. Sebelum lahirnya UndangUndang No. 22 tahun 1999 tentang pemerintahan daerah, Provinsi Bengkulu disebut Provinsi Daerah Tingkat I Bengkulu, sedangkan kabupaten dan kota disebut sebagai Daerah Tingkat II. ${ }^{1}$ Provinsi ini dibentuk pada tanggal 18 Nopember 1968 berdasarkan Undang-Undang No. 9 Tahun 1967 Juncto Peraturan Pemerintah No. 20 Tahun 1968. Pada awal pembentukannya hingga tahun 2002, Provinsi Bengkulu dengan luas $19.978 \mathrm{Km}^{2}$ terdiri dari 3 (tiga) Kabupaten, 1 (satu) Kotamadya Daerah Tingkat II, 31 Kecamatan, 28 Perwakilan Kecamatan dan 1.083 Desa/Kelurahan². Pembagian wilayah Provinsi Daerah Tingkat I Bengkulu adalah sebagai berikut

\footnotetext{
${ }^{1}$ Setelah UU No. 22 tahun 1999, sebutan menjadi Pemerintah Provinsi, Pemerintah Kabupaten, dan Pemerintah Kota.

${ }^{2}$ Beberapa desa dan kecamatan hingga pada akhir tahun 2002 sudah banyak yang dimekarkan dan defenitif.
} 
: Kabupaten Daerah Tingkat II Bengkulu Selatan; Rejang Lebong; Bengkulu Utara, dan Kotamadya Daerah Tingkat II Bengkulu. Sedangkan jumlah penduduk Provinsi Bengkulu pada akhir tahun 1994 berjumlah 1.320.400. jiwa, dengan pertumbuhan selama 3 tahun terakhir (1990 s/d 1993) rata-rata sebesar 3,9\% per tahun.

Tahun 2003 merupakan tahun istimewa bagi Provinsi Bengkulu setelah beberapa kabupaten baru berdiri yaitu Kabupaten Kepahiyang dan Kabupaten Lebong (dimekarkan dari Kabupaten Rejang Lebong), Kabupaten Muko-Muko (dimekarkan dari Kabupaten Bengkulu Utara), Kabupaten Seluma dan Kabupaten Kaur (dimekarkan dari Kabupaten Bengkulu Selatan). Sehingga hingga saat ini jumlah kabupaten dan kota di Provinsi Bengkulu adalah 10 daerah. Terakhir pada tanggal 24 Juni 2008, disahkan UU No. 24 tahun 2008 tentang Pembentukan Kabupaten Bengkulu Tengah hasil pemekaran dari Kabupaten Bengkulu Utara.

Secara administratif, Kota Bengkulu terbagi atas 9 kecamatan yakni Kecamatan Gading Cempaka, Teluk Segara, Muara Bangkahulu, Selebar, Kampung Malayu, Sungai Serut, Ratu Samban, dan Ratu Agung. Pada awalnya, kota Bengkulu terdiri dari hanya 4 kecamatan yakni kecamatan Selebar, Teluk Segara, Gading Cempaka dan Muara Bangkahulu.

Berkaitan dengan asal usul penduduk yang mula-mula mendiami kota Bengkulu, belum banyak terungkapkan. Namun demikian, menurut cerita-cerita orang tua suku Melayu Bengkulu merupakan suku asli atau asal. Suku Melayu Bengkulu ini ada yang menduga berasal dari suku bangsa Rejang Sabah (Jang Sebeak) atau rakyat dari Kerajaan Sungai Serut yang berasimilasi dengan suku bangsa Minangkabau yang datang pada masa awal pemerintahan Kerajaan Sungai Lemau semasa Kerajaan Pagaruyung di Minangkabau (Herlina, 1997 ; 19). Disebutkan dalam tambo bahwa dahulunya orang Minangkabau datang ke daerah Bengkulu dibawah pimpinan. Datuk Bagindo Mukaraja Sakti yang menjadi suami dari Putri Gading Cempaka dari Kerajaan Sungai Lemau. Pada masa Kerajaan Sungai Lemau berdatangan pula berbagai suku bangsa dari pelosok nusantara lainnya seperti Jawa, Bugis, Banten, Palembang, Lembak dan Lampung. Mereka menetap di bandar Pasar Bengkulu dan sekitarnya dan antara mereka dengan penduduk kerajaan Sungai Lemau terjadi asimilasi. Keturunan dari asimilasi tersebut itulah yang menjadi cikal bakal adanya suku Melayu Bengkulu di Kota Bengkulu.

Penduduk kota Bengkulu pada tahun 2002 adalah 304.188 jiwa dengan jumlah penduduk miskin 33.504 jiwa (10,9\%) dari populasi penduduknya) dan tingkat kesenjangan kemiskinannya (Poverty Gap) berkisar 1,81. Angka ini adalah tidak mutlak karena tingkat penyebaran penduduk miskinnya yang tidak merata. Pada tahun 2004, penduduk kota Bengkulu tercatat 380.772 jiwa dengan kepadatan 2,946 setiap kilometer, sedangkan di tahun 2006 jumlah penduduk 
Kota Bengkulu tercatat 261.620 jiwa. Komposisi penduduk tesebebut pada tahun 2016 mengalami perubahan yang cukup signifikan. Berdasarkan data BPS tahun 2016, pada tahun 2015 jumlah penduduk Kota Bengkulu mencapai 351.298 jiwa sedangkan tahun 2014 berjumlah 342.9 ribu jiwa dengan rasio jenis kelamin penduduk sebesar 101. Artinya diantara 100 penduduk perempuan terdapat 101 penduduk laki-laki (BPS. 2016: 39).

Penduduk Kota Bengkulu terdiri dari beberapa suku bangsa, dengan penduduk asal (asli) adalah suku Melayu Bengkulu dan Lembak. Penduduk pendatang antara lain Serawai, Pasemah, Rejang, Jawa, Minang, Batak, Bugis, Sunda dan Cina. Dilihat dari suku bangsa yang mendiaminya, maka Suku Melayu Bengkulu menduduki peringkat pertama dari sisi jumlah penyebaran penduduk di Kota Bengkulu yakni mencapai 41.974 jiwa. Selanjutnya, posisi kedua ditempati suku Serawai sebanyak 41.841 jiwa, suku Jawa sebanyak 38936 jiwa, suku Minang sebanyak 33.199 jiwa, dan suku Rejang sebanyak 20. 313 jiwa. Sementara suku Lembak menempati peringkat ke-6 dengan 12.411 jiwa, disusul suku Sunda Pariangan sebanyak 7.248 jiwa dan yang terakhir suku Melayu Pasemah sebanyak 6497 jiwa (BPS Bengkulu, 2000). Data penyebaran suku di Kota Bengkulu tersebut merupakan hasil sensus penduduk tahun 2000 dan merupakan data terakhir yang dimiliki BPS Bengkulu.

Suku bangsa Lembak mendiami Kelurahan Tanjung Agung, Tanjung Jaya, dan Dusun Besar yang juga merupakan lokasi Danau Dendam Tak Sudah. Suku bangsa ini juga mengklaim sebagai penduduk asli Kota Bengkulu dan menganggap mereka berbeda dengan suku bangsa Lembak lainnya yang ada di Kabupaten Rejang Lebong (mulai dari daerah Kepala Curup hingga perbatasan Lubuk Linggau), dan yang ada di Kabupaten Musi Rawas (terutama di Muara Bliti).

Secara budaya Kelurahan Tanjung Agung dan Kelurahan Tanjung Jaya tidak dapat dipisahkan. Daerah ini diyakini sebagai permukiman awal suku bangsa Lembak Delapan dalam wilayah Kerajaan Sungai Serut. Secara administratif dua kelurahan ini masuk dalam Kecamatan Sungai Serut bersama 5 kelurahan lainnya. Demikian juga kesenian Barong Landong diyakini lahir di Kelurahan Tanjung Agung sehingga Barong Landong yang di Kota Bengkulu disebut dengan nama Barong Landong Tanjung Agung.

\section{Sejarah Barong Landong}

Barong Landong indentik dengan Desa Tanjung Agung karena diyakini tercipta di desa tersebut masa pemerintahan Hindia Belanda. Tidak banyak masyarakat Kelurahan Tanjung Agung saat ini yang mengetahui sejarah Barong Landong. Bapak Tajuddin selaku ketua adat 
juga tidak mengetahui persis sejarahnya. Demikian juga Bapak Bastari selaku ketua Sanggar Puralis (Putri Rambut Lingkar Sembilan) yang membina kesenian Barong Landong juga tidak mengetahui kecuali dari tulisan Nachrowi (1990). Kelangkaan informasi ini diakibatkan Barong Landong sudah tidak pernah lagi ditampilkan sejak tahun 1950an. Beberapa orang tua yang berumur sekitar 70 tahun saat ini pernah melihat pertunjukan barong landong ketika mereka masih anak-anak.

Keberadaan Barong Landong pada masyarakat Lembak di Kota Bengkulu atau di Kelurahan Tanjung Agung secara khusus dapat dikelompokkan dalam tiga periode:

1. Masa pembuatan barong landong pertama sekali yang diyakini pada tahun 1800 -an

2. Masa penggalian kembali melalui penelitian tahun 1990

3. Masa pengembangan dan upaya pelestarian sejak tahun 2012

Periode ini dibagi berdasarkan penciptaan dan pemanfaatan barong landong di masyarakat. Periode pertama adalah masa penciptaan kesenian barong landong oleh masyarakat Tanjung Agung. Tidak ada yang mengetahui persis tahun penciptaannya namun diperkirakan sebelum tahun 1900 atau tahun 1800-an. Kesenian ini menjadi hiburan alternatif sekaligus sebagai media ucapan syukur masyarakat atas hasil panen sawah yang diperoleh saat itu. Kesenian ini bertahan hingga masuknya Jepang ke Bengkulu yang melarang kesenian barong landong ditampilkan. Disisi lain sulitnya kehidupan ekonomi ketika itu juga menyebabkan masyarakat tidak lagi memikirkan barong landong. Sejak saat itu barong landong hilang dari kehidupan sehari-hari orang lembak di Tanjung Agung.

Pada tahun 1990, kesenian barong landong kembali digali melalui proses penelitian dan rekonstruksi yang dilakukan oleh Taman Budaya Bengkulu. Kegiatan ini diprakarsai oleh Bapak H. R. Roesman Moehiman yang saat itu menjabat Kepala Taman Budaya Bengkulu (Semarak Bengkulu, 19 Oktober 1992). Seperti yang diungkapkan dalam tulisan Nachrowi (1990), proses penggalian tersebut menjadi titik awal diperkenalkannya kembali barong landong ke masyarakat Kota Bengkulu. Dalam kegiatan tersebut dari hasil penelitian juga dilakukan rekonstruksi yaitu membuat kembali barong landong sesuai dengan petunjuk beberapa orang tua yang masih mengingat wujud barong landong tersebut. Ketika itu masyarakat menyambut gembira adanya hiburan alteratif bagi masyarakat yang masih sangat terbatas sarana hiburan.

Namun upaya mempertahankan keberadaan barong landong terhenti dengan berbagai alasan. Alasan utama adalah tidak adanya yang mengelola secara khusus karena terkait anggaran pemeliharaan dan operasional. Beberapa asset terkait barong landong di Taman Budaya Bengkulu 
saat ini sudah tidak bisa ditemukan seperti kaset rekaman musik pengiring barong landong, buku dan laporan penelitian yang dilakukan tahun 1990 oleh tim Nachrowi, dan foto-foto dalam bentuk cetak maupun film seluloit. Menurut Bapak Buyung Asril (Kepala Taman Budaya Bengkulu saat ini), tidak dikelolanya Taman Budaya Bengkulu dengan baik selama ini sehingga beberapa arsip maupun koleksi perpustakaan tidak ditemukan lagi berbeda ketika masih menjadi UPT Kemendidikan Pendidikan dan Kebudayaan. Bapak Devi (staf Museum Negeri Propinsi Bengkulu dan juga pembuat barong landong) mengungkapkan bahwa barong landong yang dibuat pada tahun 1990 tersebut tidak terawat dan dibawa ke rumah beliau untuk dipelajari teknik pembuatannya dan selanjutnya diserahkan ke Museum Negeri Propinsi Bengkulu hingga saat ini menjadi bagian dari koleksi museum tersebut.

Setelah sejak 1990 tidak ada lagi pertunjukan Barong Landong oleh Taman Budaya Bengkulu, dan semakin hilang dalam ingatan kolektif masyarakat Bengkulu dan Tanjung Agung. Pada tahun 2012 ingatan kolektif tersebut digugah kembali oleh Pak Devi melalui Sanggar Anggrek Bulan mencoba merevitalisasi kesenian barong landong dengan membuat barong landong baru. Demikian juga Sanggar Puralis yang dibina oleh Bapak S. Effendi yang juga ketua Badan Musyawarah Adat Kota Bengkulu ikut mengaktifkan kembali barong landong5 . Para sesepuh yang pernah terlibat dalam pembuatan dan pertunjukan barong landong tahun 1990 dikumpulkan kembali. Dalam pertemuan tersebut disepakati untuk membuat kembali barong landong dan memperkenalkannya sebagai kesenian masyarakat lembak. Rencana tersebut berhasil diwujudkan dan pada tanggal 1 Muharam untuk pertama kalinya ditampilkan dan ikut pada arak-arakan perayaan tabut tahun 2012.

Dalam tulisan Nachrowi (1990), menurut mitologi yang diyakini oleh masyarakat Desa Tanjung Agug, Barong Landong terkait dengan sebuah keluarga yang menanam tanaman rumbia dan kelapa. Keluarga tersebut mencari lahan yang tepat untuk ladangnya. Mereka menemukan lahan berupa rawa-rawa untuk menanam rumbia dan pohon kelapa ditanam di dataran kering sekitar tanaman rumbia. Sambil menunggui ladang, mereka sepakat membangun pondok sebagai tempat tinggal mereka. Lokasi ladang dan tempat tinggal mereka tersebut diberi nama Tanjung Agung Pasar Geting yang artinya sebuah desa agung yang berada dekat dengan sebuah tanjung sehingga daerahnya selalu terendam air. Selain bercocok tanam, keluarga tersebut juga memelihara kerbau dan sapi di dataran yang lebih tinggi di daerah tersebut. Suatu hari sapi yang sedang digembala dihinggapi seekor burung putih. Adanya burung putih tersebut dimaknai oleh suami istri tersebut bahwa daerah tersebut sangat baik untuk pertanian. Selanjutnya keluarga tersebut membuka lahan persawahan dengan menanam padi dan menghasilkan panen yang 
cukup besar. Hasil panen yang besar tersebut mengundang warga lainnya untuk membuka lahan pertanian di daerah tersebut. Ketika panen tiba secara gotong royong seluruh warga memanen padi. Pada panen padi pertama tersebut disambut gembira dengan mengadakan acara hiburan dengan mendirikan balai atau pondok-pondok sebagai tempat melaksanakan acaraa. Untuk memeriahkan acara yang dimaksud ketua adat (pasirah) mengusulkan untuk membuat orangorangan yang besar dan tinggi dengan menggunakan pakaian yang bagus. Orang-orangan tersebut terdiri dari laki-laki dan perempuan dengan pakaian pengantin. Sepasang orang-orangan tersebut dianggap sangat berjasa terhadap hasil panen mereka berupa kemakmuran dan keamanan masyarakat tersebut. Usul tersebut disetujui oleh warga dan membuat orang-orangan yang sangat besar dan diberi nama barong. Sedangkan karena sangat tinggi atau panjang masyarakat menyebut dengan nama landong. Sejak peristiwa tersebut setiap selesai panen padi, masyarakat selalu membuat barong landong sebagai tanda puji syukur serta bentuk permainan dan tarian. Untuk mengiringi tarian tersebut mereka menggunakan alat musik berupa kelintang, redap, dan gong.

Menurut Bapak S. Effendi, sejarah dan konsep barong landong sangat terkait dengan sejarah suku bangsa lembak tersebut. Suku bangsa lembak diyakini adalah sekelompok manusia yang melakukan migrasi dari wilayah kerajaan Kutai Kartanegara di Kalimantan menuju wilayah Bangka Belitung saat ini lalu ke Bengkulu hingga akhirnya ke wilayah Betawi di Jakarta. Pada setiap daerah yang disinggahi menetap beberapa orang anggota rombongan. Hal ini menurut Bapak Effendi bisa dilihat dari bahasa yang memiliki kemiripan.

Khusus di wilayah Bengkulu, 2 orang kakak beradik menetap dan mendirikan Kerajaan Anak Dalam dengan raja bernama Rajo Anak Dalam. Selanjutnya adik perempuannya pergi ke wilayah Lubuklinggau sekarang dan menjadi cikal bakal keturunan orang lembak yang ada di wilayah Musi Rawas, Lubukliggau, dan Kecamatan Padang Ulak Tanding.

Terkait barong landong menurut Bapak S. Effendi, mendapat pengaruh dari kebudayaan Tionghoa (Cina). Pengaruh Cina pada masa dahulu sudah sangat kuat terutama dalam perdagangan. Interaksi masyarakat lembak secara khusus dengan orang Cina berlangsung cukup lama sehingga ada beberapa kata Cina yang diserap dalam bahasa lembak. Salah satunya adalah kosa kata barong yang dalam bahasa Cina berarti boneka besar. Sedangkan landong atau dalam logat asli lembak disebut landung adalah kosa kata untuk menyebut sesuatu yang besar dan tinggi. Dengan demikian barong landong merupakan penamaan untuk pertunjukan boneka besar dan tinggi. Dalam dialek lembak penyebutan barong berbeda dengan penyebutan bahasa Indonesia. Menurut Bapak Bastari, dalam bahasa lembak barong diucapkan dengan huruf " $r$ " 
yang tidak jelas atau dalam penulisannya menggunakan huruf " $g h$ ” sehingga tulisan barong adalah baghong

Menurut Bapak S. Effendi, masuknya Cina ke Bengkulu membawa permainan tradisional dan menampilkannya dalam setiap acara mereka. Hal ini menjadi inspirasi bagi masyarakat lembak untuk membuat sebuah permainan yang berasal dari orang-orangan sawah (kebangkebang). Hingga akhirnya terbentuklah sebuah boneka besar dengan tinggi sekitar 2,5 meter yang digerakkan oleh manusia yang masuk ke dalam tubuh si boneka. Boneka besar tersebut dinamai baghong landung sesuai dengan logat lembak.

\section{Struktur Barong Landong}

Barong landong terdiri dari tiga bagian utama yaitu kepala, badan, tangan, dan bawah. Seluruh bahan yang digunakan berasal dari alam berupa kayu, rotan, dan tali. Barong landong memiliki tinggi badan 2,5 meter dan garis tengahnya sekitar 1 meter.

\section{a. Pembuatan Barong Landong}

1). bahan dasar kerangka barong landong

- kayu untuk membuat bagian kepala

- bambu sebagai kerangka vertikal

- rotan sebagai kerangka horizontal yang berbentuk bulatan

- tali dan paku untuk menyatukan kerangka vertikal dan horizontal

2). Bahan pelengkap

- kain beludru untuk baju tabur atau baju panjang secukupnya

- kain songket 2 lembar

- bahan singal atau mahkota kepala pria dan wanita

- properti pengantin pria dan wanita

3). Cara Pembuatan

1. kepala barong landong, dibuat dengan menggunakan bahan kayu pilihan agar awet dan tahan serta tidak dimakan rayat. Untuk memudahkan pengerjakannya, kayu dipilih yang halus agar didapat hasil yang lebih baik sesuai yang diinginkan. Pembuatan kepala barong landong biasanya dilaksanakan oleh para sesepuh adat karena mereka lebih mengetahui baggaimana bentuk yang sesuai dengan anatomi atau kerangka dari barong landong itu. Dalam pembuatannya, pertama-tama dibuat pola kepala lebih dahulu setelah itu dipahat sesuai dengan pola yang digambar. 
2. bambu bahan kerangka badan atau vertikal. Bambu dipilih yang sudah tua tetapi belum kering agar awet dan mudah mengerjakannya. Bambu ditebang sesuai dengan waktu yang tepat agar tidak diserang oleh hama kayu. Setelah bambu yang baik diperoleh, lalu dipotong sepanjang 4 meter dan dibelah selebar $5 \mathrm{~cm}$ sesuai dengan kebutuhan pembuatan kerangka barong landong. Belahan bambu tersebut dibentuk berupa lengkungan untuk bagian bahu atau pundak dengan cara bambu dipanaskan di atas tungku api agar mudah dibentuk.

3. Rotan. Rotan yang dipakai adalah yang sudah tua dan mempunyai diameter sekitar 3 $\mathrm{cm}$. Rotan yang telah dibersihkan selanjutnya dijemur hingga setengah kering. Lalu dipotong sebanyak yang diperlukan. Selanjutnya rotan dibentuk berupa lingkaran dengan diameter sekitar $74 \mathrm{~cm}$ dengan cara dipanaskan di atas tungku api sehingga lingkarannya cukup baik.

4. Tali (alat pengikat), tali terbuat dari rotan yang kegunaannya untuk menyatukan bambu vertikal dengan rotan horizontal sehingga terbentuklah kerangka barong landong

5. Pembuatan tangan. Tangan barong landong terbuat dari:

a. Bambu

Bambu dipilih yang kecil dan keras dengan diameter sekitar 3,5 cm dan panjangnya sekitar 6 ruas. Bambu dipotong dalam 4 bagian dengan memisahkan masing-masing ujungnya yang terdapat ruas kurang lebih $3 \mathrm{~cm}$ sebagai tempat sambungan. Setelah potongan-potongan bambu tersebut dibersihkan dan dibuat lubang pada setiap ujung kemudian bambu pertama dan kedua disatukan dengan mengikat dengan kawat yang telah tersedia. Demikian juga bambu yang ketiga dan keempat. Harus diperhatikan bahwa ikatan kawat tidak boleh terlalu kuat agar tangan tersebut dapat digerakkan.

b. Kayu

Kayu yang dipakai adalah kayu yang keras dan kering dengan ukuran panjang kali lebar kali tebal sekitar 30 kali 20 kali $10 \mathrm{~cm}$. Kayu tersebut dibentuk atau diukir menyerupai tangan mulai dari pergelangan hingga kelima jari-jarinya. Pada bagian pergelanggan diukir lebih kecil. Kedua tangan dibuat dua buah untuk kiri dan kanan lalu disatukan ke dalam bambu yang telah dibentuk sebagai bahu dengan memasukkan ujung kayu dan diikat dengan tali. 
6. Kawat

Kawat yang dipilih adalah kawat halus dan tidak mudah putus. Kawat berfungsi untuk mengikat setiap sambungan sehingga bagian tubuh gampang digerakkan.

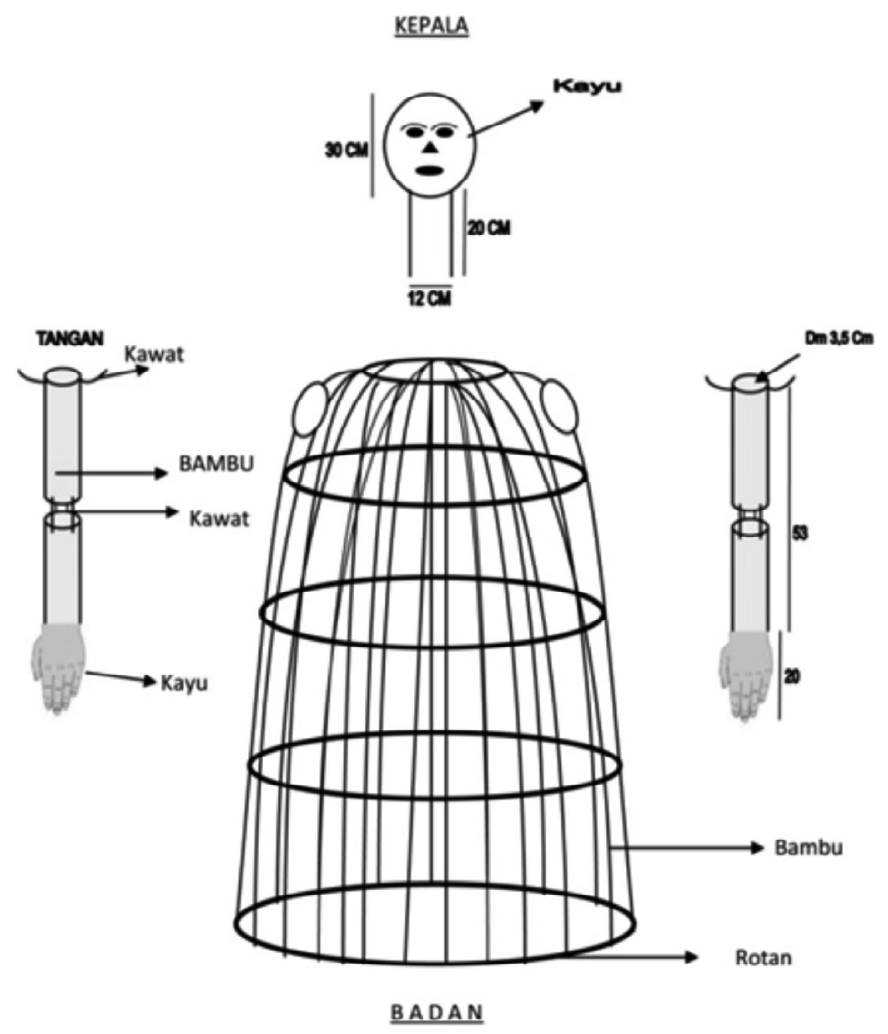

Gambar 1 Sketsa rangka barong landong

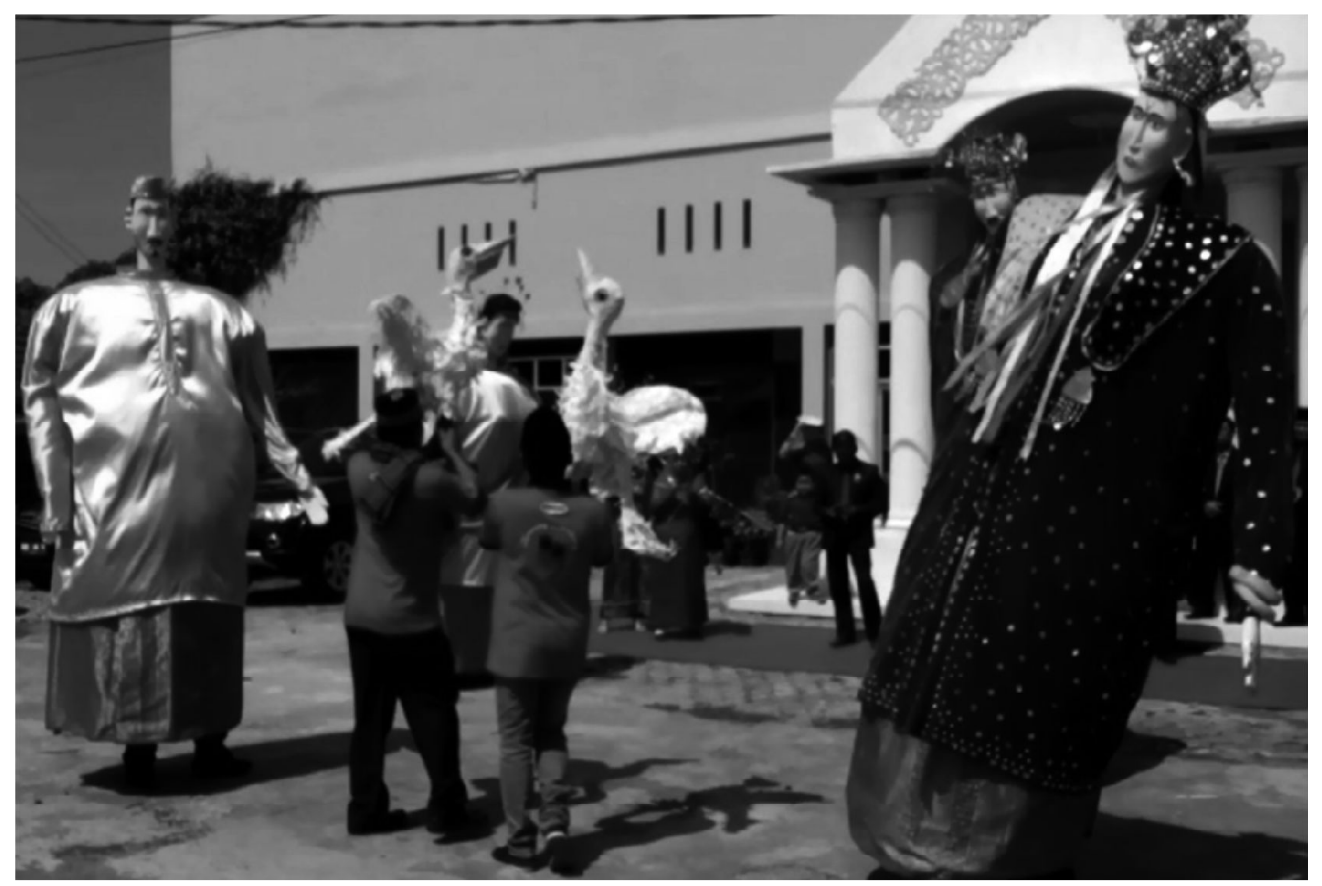

Gambar 2 Salah satu pertunjukan Barong Landong 


\section{b. Mainan Burung Lanting}

Burung lanting adalah nama jenis burung yang sering datang ke sawah-sawah saat petani mengolah sawah. Burug lanting menjadi penting dalam pertunjukan barong landong karena dianggap dari bagian dari pengolahan sawah bersama kebang-kebang (orang-orangan sawah). Mainan burung lanting dibuat dari rangka kayu atau besi yang selanjutnya dilapisi dengan kertas putih sesuai dengan warna burung tersebut.

Mainan burung lanting dimainkan sebagai pengiring gerak tari barong landong. Burung lanting yang dimainkan sepasang oleh dua orang laki-laki dengan cara diayun-ayunkan ke atas menyerupai terbang burung tersebut.

\section{Penampilan Barong Landong}

\section{a. Waktu}

Pelaksanaan tradisi barong landong dilaksanakan pada musim panen tiba. Setelah padi dipotong lalu disimpan ke dalam lumbung padi yang disebut kiang. Disaat menunggu musim tanam, para petani melakukan permainan barong landong sebagai ungkapan kegembiran mereka dengan diiring oleh tari-tarian dan musik.

\section{b. Tata Cara Penampilan}

Penampilan barong landong merupakan bagian dari pelaksanaan upacara atau kenduri ucapan syukur terhadap hasil panen dengan makan bersama dan doa kepada yang maha kuasa atas berkah yang diterima. Setelah acara makan bersama, dilanjutkan dengan acara hiburan berupa penampilan barong landong. Disaat inilah warga ikut menari mengikuti gerakan barong landong. Sebelum barong landong ditampilkan, terlebih dahulu dilakukan doa selamatan agar orang yang mengenakan barong landong tidak diganggu oleh makhluk halus. Doa tersebut dilakukan dengan pembakaran kemeyan yang dilakukan oleh ketua adat lalu diasapkan ke seluruh tubuh barong landong. Setelah doa dilakukan, selanjutnya kepala , dipasangkan ke kepala orang yang ada di dalam tubuh barong landong, pemasangan tangan, aksesoris lainnya sehingga barong landong utuh menyerupai boneka raksasa. Setelah lengkap, barong landong dibawa ke tempat upacara atau keramaian sebagai hiburan.

Acara selamatan atau mendoa atau istilah lembak disebut disabo dilakukan pada saat barong landong dikeluarkan dari tempat penyimpanannnya untuk sebuah pertunjukan. Bahanbahan yang diperlukan adalah nasi punjung (nasi kuning yang dilengkapi dengan ayam 
panggang), limau, apem bekuah, kemeyan, dan kopi pahit. Sebenarnya kalau dilihat dari pelaksanaannya, ada dua tindakan yang dilakukan pada selamatan ini, yaitu acara makan bersama keluarga barong landong dan pewarisnya (termasuk para pemain) dengan menikmati hidangan yang telah disediakan. Tindakan yang kedua adalah para fisik barong landong itu sendiri yaitu dengan membakar kemenyan dan mengasapi dan memercikkan air limau ke seluruh bagian fisik barong landong sambil mengucapkan doa keselamatan bagi yang menggunakannnya.

\section{c. Musik Pengiring}

Musik pengiring barong landong adalah musik yang menggunakan kelintang, redap, dan gong. Musik pengiring dibagi menjadi tiga bagian, yaitu:

1. Irama memanggil tamu

2. Pengiring tari barong landong atau sering dinamakan kelintang tige

3. Irama burung lanting atau dinamakan kelintang tujuh.

\section{d. Tari dan Gerak}

Tari barong landong merupakan tari improvisasi dimana gerak pada tari tersebut tidak terdapat ketentuan khusus. Dalam tarian tersebut hanya ada gerakan sembah, maju mundur, gerak samping, gerak serong, gerak samping sambil melenggang, gerakan mengejar penonton, gerakan memukul penonton, gerakan-gerakan improvisasi.

\section{LAGU IRINGAN TARI BARONG LANDONG}

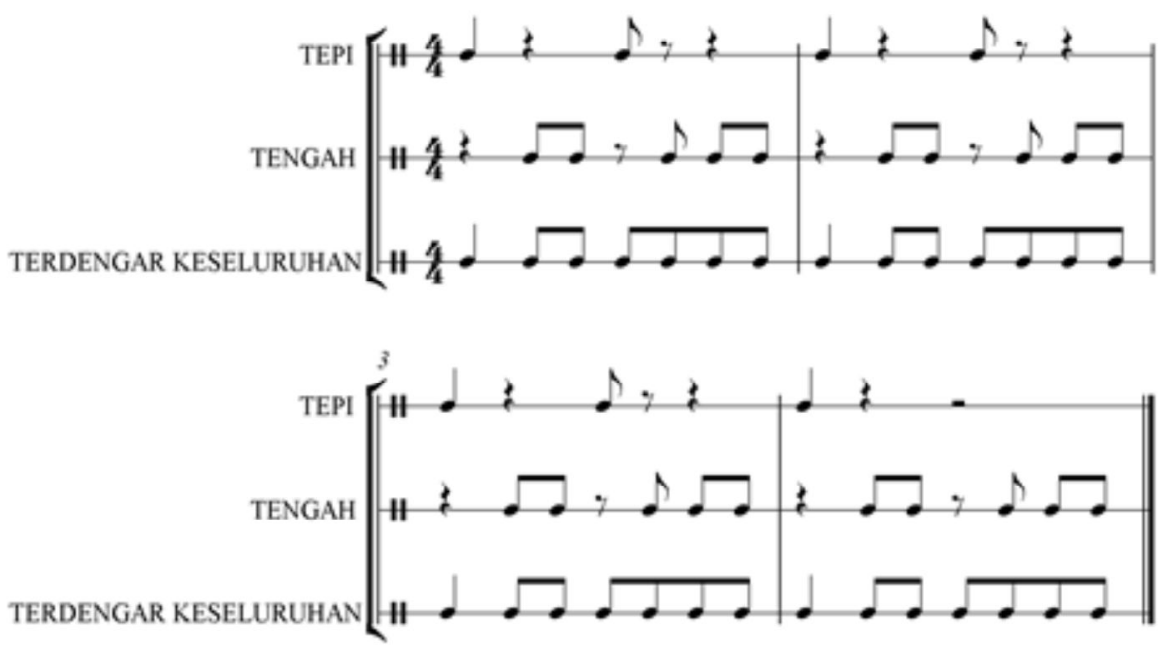

(ditulis ulang oleh Mutiara Alhusnah,S.Sn dari Nachrowi, 1990) 


\section{PUKULAN GONG \\ "LAGU MEMANGGIL TAMU"}

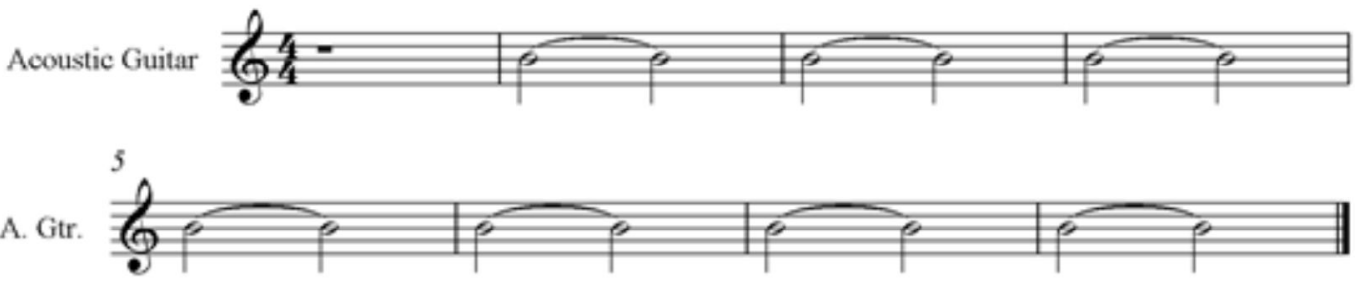

(ditulis ulang oleh Mutiara Alhusnah,S.Sn dari Nachrowi, 1990)

\section{Fungsi dan Pelestarian Barong Landong Sebagai Identitas Orang Lembak}

\section{Fungsi Barong Landong}

Barong landong pada awal pembuatannya berfungsi sebagai hiburan dan ucapan syukur atas hasil panen padi sawah yang diperoleh oleh masyarakat Tanjung Agung. Pada perkembangan selanjutnya, barong landong sudah difungsikan sebagai hiburan di berbagai kegiatan seperti acara adat pernikahan.

Besarnya dana operasional penampilan barong landong menjadi salah satu penyebab jarangnya barong landong ditampilkan terutama sebelum tahun 2012. Untuk membuat satu pasang barong landong lengkap dengan baju dan asesorisnya dibutuhkan biaya sekitar Rp5.000.000,- ditambah alat-alat musik pengiring, para pemain barong landong, penari, dan pemain musik. Biasanya biaya tersebut ditanggung oleh penyelenggara hajatan. Sejak tahu 2012, ketika barong landong mulai dikelola oleh Sanggar Puralis, maka penampilan barong landong sudah terencana dan dikelola dengan baik. Masyarakat bisa memanfaatkan pertunjukan barong landong sebagai hiburan di pesta pernikahan atau kegiatan lainnya dengan tidak perlu mengeluarkan biaya yang cukup besar.

Walau sudah dikelola oleh Sanggar Puralis, barong landong tetap menjadi milik masyarakat Tanjung Agung karena penamaan barong landong tetap menyebutkan barong landong Tanjung Agung. Saat ini bisa dikatakan bahwa barong landong bukan lagi hanya milik masyarakat Tanjung Agung tetapi sudah menjadi milik warga Kota Bengkulu karena sudah ditampilkan pada berbagai kegiatan tingkat Kota Bengkulu maupun propinsi.

Fungsi barong landong bagi masyarakat lembak Tanjung Agung dan sekitarnya sebagai hiburan saat panen sawah telah berubah. Masyarakat lembak di Tanjung Agung tidak pernah lagi menampilkan hiburan barong landong pada saat panen pandi selesai. Hal ini disatu sisi 
disebabkan telah berubahnya sistem atau pola tanam padi sawah. Ketika sistem marga di Bengkulu masih terapkan, seluruh aktifitas masyarakat diatur oleh pasirah (pemimpin marga) seperti pola bercocok tanam padi sawah. Pasirah menetapkan jadwal mengolah tanah, menanam, dan panen padi secara tegas yang harus dipatuhi oleh masyakarat. Dengan demikian masa panen padi dilakukan secara serentak. Berbeda dengan saat ini, pola pengolahan padi sawah tidak lagi diatur seperti sebelumnya, masyarakat sudah mengolah sawahnya sesuai dengan kepentingan masing-masing dengan demikian tidak ada lagi tahapan pengolahan sawah secara serentak.

Dilihat dari fungsinya saat ini, barong landong tidak dapat dijadikan sebagai identitas budaya orang lembak. Ketika tidak menjadi bagian aktivitas sehari-hari, maka secara fungsional sudah berada di luar komunitas atau suku bangsa lembak. Satu-satunya penanda barong landong berasal dari suku bangsa lembak adalah penggunaan asesoris pada sepasang barong landong dan masih dipertahankannya mitologi asal usul penciptaan barong landong.

Para pelaku seni di Kota Bengkulu memanfaatkan barong landong sebagai media kretivitas mereka dalam menciptakan variasi barong landong. Secara ekonomi, barong landong belum memberikan keuntungan bagi seniman Bengkulu karena belum menjadi kesenian yang populer seperti orgen tunggal yang banyak diundang untuk hiburan di perayaan pernikahan dan lain-lain.

Undangan penampilan barong landong masih terbatas pada kegiatan-kegiatan tertentu seperti acara pemerintahan dan pernikahan bagi masyarakat yang berminat terhadap kesenian barong landong. Kurangnya minat masyarakat juga disebabkan masih monotonnya gerakan barong landong yang hanya melakukan gerakan kecil seperti memutar, berjalan, bergoyanggoyang mengikuti irama musik. Demikian juga burung lanting yang dibawa tidak memberikan sesuatu yang membuat penonton kagum.

Sejak tahun 2012, barong landong mulai dimunculkan kembali ke masyarakat umum Kota Bengkulu yang dimotori oleh Sanggar Puralis. Berbagai kegiatan atau perayaan sering menampilkan barong landong. Beberapa kegiatan pemerintahan yang menampilkan barong landong adalah:

1. Perayaan HUT Proklamasi Republik Indonesia

2. Perayaan HUT Kota Bengkulu

3. Perayaan HUT Propinsi Bengkulu

4. Perayaan festival tabut 
Menurut Bapak Bestari, barong landong sudah sering ditampilkan dalam kegiatan pemerintahan namun hingga saat ini belum ada realisasi pengelolaan oleh Pemerintah Kota Bengkulu maupun Propinsi Bengkulu terkait barong landong. Pemerintah daerah hanya sering mengundang untuk tampil tetapi tidak pernah memberikan bantuan pembinaan dalam bentuk materi maupun bentuk lainnya. Walaupun secara pribadi gubernur pernah berbicara akan mengembangkan barong landong hingga menjadi ikon Bengkulu, namun tindak lanjut rencana tersebut tidak ada.

\section{Upaya Pelestarian}

Barong landong yang terkesan monoton telah mendapat sentuhan kreasi baru agar lebih diminati oleh masyarakat luas. Beberapa modifikasi dilakukan terhadap barong landong dan pemberian keleluasaan bagi masyarakat untuk mengembangkannya.

Bapak S. Effendi selaku pembina Sanggar Puralis telah mengklasifikasikan barong landong dalam dua kelompok yaitu:

1. Barong landong agung, yaitu baru landong yang mengikuti bentuk asli yaitu memiliki tinggi 2,5 meter, bahan terbuat dari bambu, rotan, dan kayu, menggunakan asesoris berupa pakaian pengantin lembak. Barong landong agung hanya terdapat 1 pasang yaitu yang tersimpan di Sanggar Puralis. Barong landong agung hanya ditampilkan untuk acara-acara khusus yang bersifat resmi atau perayaan hari besar dan saat mengeluarkannya harus melakukan acara selamatan serta barong landong disabo.

2. Barong landong keluarga, yaitu barong landong yang bersifat kreasi tetapi harus mengikuti ketentuan yaitu tidak boleh lebih tinggi atau harus lebih rendah dari barong landong agung. Barong landong keluarga ini sudah banyak yang terbuat dari bahan fiber sehingga lebih ringan, motif pakaian juga bebas seperti batik atau kain basurek.

Modifikasi sebagai upaya menarik minat masyarakat luas juga dilakukan terhadap musik pengiring yang sebelumnya hanya musik instrumental dari redap, kulintang, gendang, dan serunai yang dimainkan langsung oleh para pemain musik diganti dengan musik dan lagu baghong landung namun tetap mengikuti irama seperti musik sebelumnya. Lagu ini diciptakan oleh Bapak S. Effendi agar masyarakat mengetahui apa itu barong landong.

Dalam pegelolaan barong landong, Badan Musyawarah Adat Kota Bengkulu telah memasukkan barong landong sebagai salah satu kesenian khas Kota Bengkulu dan setiap pembuat atau pemilik barong landong harus saling berkordinasi dengan Badan Musyawarah 
Adat. Agar barong landong dikenal lebih luas, Badan Musyawarah Adat Kota Bengkulu pernah mengusulkan kepada Pemerintah Propinsi Bengkulu agar diletakkan sepasang barong landong di Anjungan Propinsi Bengkulu Taman Mini Indonesia Indah di Jakarta namun hingga saat ini belum dapat direalisasikan.

\section{PENUTUP}

Suku bangsa lembak di Kota Bengkulu diperkirakan memiliki hubugan dengan suku bangsa lembak di daerah Sumatera Selatan, dengan masyarakat Bangka Belitung, suku bangsa Betawi di Jakarta yang dilihat dari kedekatan bahasa.

Salah satu kesenian orang lembak di Bengkulu yaitu barong landong yang lahir di Desa Tanjung Agung. Barong landong terinspirasi dari kebang-kebang yang ada di sawah sehingga diciptakan boneka berwujud sepasang manusia yang besar dan tinggi. Penciptaan barong landong diyakini mendapat pengaruh dari budaya Cina yang pada tahun 1800-an sudah banyak bermukim di Bengkulu sebagai pedagang. Kesenian Cina seperti barongsai memberikan inspirasi bagi orang lembak ketika itu untuk membuat media hiburan sehingga terciptalah boneka manusia besar yang dinamai barong landung. Nama barong (oleh masyarakat lembak disebut baghong) diambil dari bahasa Cina yang berarti sejenis boneka raksasa. Sedangkan nama landong (masyarakat lembak menyebut landung) berasal dari kosa kata lembak yang berarti tinggi atau panjang. Dengan demikian barong landong berarti boneka atau orang-orangan yang tinggi besar. Demikian juga asesoris pakaian pengantin yang dipakai oleh pengantin lembak dan barong landong banyak mendapat pengaruh budaya Cina.

Barong landong mengalami 3 priodisasi perkembangan, yaitu masa penciptaan di abad ke-19, masa tahun 1990 saat dilakukan penggalian, dan tahun 2012 ketika barong landong diaktifkan lagi sebagai sarana hiburan dalam berbagai kegiatan dan perayaan.

Perubahan yang dilakukan terhadap barong landong tidak hanya dalam bentuk fisik, tetapi juga perlakuan terhadap kesenian itu sendiri sudah mengalami perubahan. Secara fisik barong landong tidak hanya terbuat dari kayu tetapi sudah dimodifikasi dengan menggunakan bahan fiberglass sehingga lebih ringan, musik pengiring yang awalnya hanya instrumental kini sudah diciptakan lagu barong landong untuk menghidupkan gerak tari. Barong landong dikelompokkan dalam 2 jenis yaitu barong landong agung yang hanya satu pasang, dan barong landong keluarga yang boleh dibuat oleh siapa saja. 
Barong landong pada awal penciptaannya berfungsi sebagai ungkapan rasa syukur masyarakat lembak di Desa Tanjung Agung terhadap hasil panen sawah. Namun saat ini ketika pengolahan sawah tidak lagi serentak sehingga masa panen padi juga tidak dapat dipastikan. Dengan demikian pelaksanaan pertunjukan barong landong tidak dapat dilakukan pada masyarakat Desa Tanjung Agung. Untuk tetap melestarikan barong landong, fungsi kesenian tersebut berubah sebagai sarana hiburan dalam berbagai kegiatan baik di Pemerintah Kota Bengkulu maupun tingkat Pemerintah Propinsi Bengkulu.

Melihat kondisi saat ini, kesenian barong landong tidak lagi hanya dimiliki oleh orang Lembak di Desa Tanjung Agung tetapi sudah berada di luar komunitas orang Lembak. Untuk itu tulisan ini merekomendasi beberapa hal yaitu:

1. Barong landong merupakan kesenian yang unik dan langka sehingga perlu dilestarikan sebagai identitas budaya orang lembak di Kota Bengkulu;

2. Perlu disosialisasikan kepada warga suku bangsa lembak agar memanfaatkan barong landong pada aktivitas budaya mereka;

3. Pemerintah Kota Bengkulu dan Propinsi Bengkulu diharapkan melakukan pembinaan terhadap seluruh bidang kesenian termasuk barong landong sehingga keberlangsungan kesenian tersebut tetap terjaga.

\section{DAFTAR PUSTAKA}

Afrizal. 2014. Metode Penelitian Kualitatif: Sebuah Upaya Mendukung Penggunaan Penelitian Kualitatif Dalam Berbagai Disiplin Ilmu. Jakarta: RajaGrafindo Persada

Anwar, M. Ichwan . "Warna Budaya Melayu Bengkulu” dalam M. Ikram, dkk. 2004. Bunga Rampai Melayu Bengkulu. Bengkulu: Dinas Pariwisata Provinsi Bengkulu

Budhisantosa, "Pendidikan Seni Dan Globalisasi Budaya Dalam Konteks Sentral Dan Strategis", Makalah seminar Nasional Pendidikan Seni Dan Globalisasi Budaya, ISI Yogyaakarta, 12 Desember 1991

Bungin, Burhan. 2007. Penelitian Kualitatif: Komunikasi, Ekonomi, Kebijakan Publik, dan Ilmu Sosial Lainnya. Jakarta: Kencana

Damsar. 2015. Pengantar Teori Sosiologi. Jakarta: Prenadamedia Group

Hamidy, Badrul Munir (Ed). 1991/1992. Upacara Tradisional Daerah Bengkulu: Upacara Tabot di Kotamadya Bengkulu. Jakarta: Depdikbud

Hidayanto. 2012. "Topeng Reog Ponorogo Dalam Tinjauan Seni Tradisi” dalam JURNAL EKSIS Vol.8 No.1, Mar 2012: 2001 - 2181

Iriani, Yondri, Rois Leonard Arios, dan Femmy. 2008. "Kesenian Tradisional: Jenis, Tokoh, dan 
Penyebarannya di Kota Padang, Bengkulu, dan Palembang”. Laporan Penelitian BPSNT Padang Koentjaraningrat, 1986. Pengantar Ilmu Antropologi. Jakarta: Aksara Baru

Lubis, Akhyar Yusuf dan Donny Gahral Adian. 2011. Pengantar Filsafat Ilmu Pengetahuan. Depok: Koekoesan

Merriam, Alan P. 1964 The Anthropology of Music. Northwestern: Northwestern University Press

Moleong, Lexy J. 2006. Metode Penelitian Kualitatif. Bandung: Remaja Rosdakarya

Mulyana, Dedy 2008. Metodologi Penelitian Kualitatif: Paradigma Baru Ilmu Komunikasi dan Ilmu Sosial Lainnya. Bandung: Remaja Rosdakarya

Soedarsono, "Pendidikan Seni Dalam kaitannya dengan keparawisataan". Makalah Seminar Dalam Rangka Peringatan Hari Jadi Jurusan Pendidikan Sendratasik ke-10 FPBS IKIP Yogyakarta, 12 Pebuari 1995

Soedarsono, "Pendidikan Seni Dalam kaitannya dengan keparawisataan". Makalah Seminar Dalam Rangka Peringatan Hari Jadi Jurusan Pendidikan Sendratasik ke-10 FPBS IKIP Yogyakarta, 12 Pebuari 1995.

Soemardjan, Selo. 1980/1981, "Kesenian dalam Perubahan Kebudayaan”, dalam Analisis Kebudayaan, Departemen Pendidikan dan Kebudayaan, Jakarta, Tahun I, Nomor 2

Strauss, Ansem dan Juliet Corbin. 2003. Dasar-Dasar Penelitian Kualitatif. Yogyakarta: Pustaka Pelajar

Sudikan, Setya Yuwana. 2010. "Ragam Metode Pengumpulan Data: Mengulas Kembali Pengamatan, Wawancara, Analisis Life History, Analisis Folklore" dalam Burhan Bungin (Ed). 2010. Metodologi Penelitian Kualitatif. Jakarta: RajaGrafindo Persada

Triadi, Meyka , Emy Wuryani, Wahyu Purwiyastuti. "Fungsi Dan Makna Kesenian Baleganjur Bagi Kehidupan Masyarakat Dusun Cetodesa Gumeng Kecamatan Jenawikabupaten Karanganyar" dalam http://www.widyasari-press.com/ diunduh tanggal 4 Maret 2017

“H.R. Roesman Moehiman: Membidani Lahirnya Kembali Barong Landong”. Semarak Bengkulu, Senin 19 Oktober 1992 